NBER WORKING PAPER SERIES

\title{
THE METHODS AND CAREERS OF LEADING AMERICAN PAINTERS IN THE LATE NINETEENTH CENTURY
}

\author{
David W. Galenson \\ Working Paper 11545 \\ http://www.nber.org/papers/w11545
}

\author{
NATIONAL BUREAU OF ECONOMIC RESEARCH \\ 1050 Massachusetts Avenue \\ Cambridge, MA 02138 \\ August 2005
}

The views expressed herein are those of the author(s) and do not necessarily reflect the views of the National Bureau of Economic Research.

(C)2005 by David W. Galenson. All rights reserved. Short sections of text, not to exceed two paragraphs, may be quoted without explicit permission provided that full credit, including (C) notice, is given to the source. 
The Methods and Careers of Leading American Painters in the late Nineteenth Century David W. Galenson

NBER Working Paper No. 11545

August 2005

JEL No.

\begin{abstract}
Although American painters of the late nineteenth century were much less influential than their European counterparts, the methods and careers of the leading American artists of the period reflect the same division between visual and conceptual approaches that characterized French art. The conceptual painters Thomas Eakins and John Singer Sargent matured early, and made individual landmark paintings, whereas the experimentalists Mary Cassatt, Winslow Homer, Albert Pinkham Ryder, and James McNeill Whistler developed more slowly, and made their contributions gradually in larger bodies of work. These American artists were less innovative than their French contemporaries, but they created approaches to art no less considered than those of their more famous counterparts.
\end{abstract}

\author{
David Galenson \\ Department of Economics \\ University of Chicago \\ 1126 E $59^{\text {th }}$ Street \\ Chicago, IL 60637 \\ and NBER \\ sogrodow@midway.uchicago.edu
}


The late nineteenth century witnessed an intensification of modern art's battles between visual and conceptual approaches to representation. The most celebrated of these took place in France, as the Impressionists fought to establish an experimental art based on perception, and were themselves subsequently challenged by a variety of conceptual approaches ranging from Symbolism to Neo-Impressionism. ${ }^{1}$ But although less publicized these differences also appeared elsewhere, including the United States. So for example although the two greatest American artists of the period were both proponents of realism, they differed sharply in their attitudes about how it could best be achieved: whereas Winslow Homer declared that "I try to paint truthfully what I see, and make no calculations," Thomas Eakins advised artists to "Paint with your brain as well as your eye." ${ }^{2}$ Art historians have devoted considerable study to the leading American artists of the time. Among the topics they have studied are the artists' working methods and the evolution of their art over the course of their careers. Yet scholars have not explicitly considered the connections between these subjects. Studies of French artists of the late nineteenth century have revealed the value of doing this, for they have shown that there is a systematic relationship between an artist's working methods and the artist's creative life cycle. ${ }^{3}$ This investigation extends this inquiry to their American contemporaries.

$\underline{\text { The Artists and the Evidence }}$

The goal in choosing the artists to be studied here was to select the most important American artists of the late nineteenth century. This was done by using six art history textbooks published since $1980 .{ }^{4}$ Six American artists born during 1830-60 had paintings reproduced in at least five of these books. These artists are the subject of this study. In addition to Homer (18361910) and Eakins (1844-1916), they include Albert Pinkham Ryder (1847-1917) and the 
expatriates Mary Cassatt (1845-1926), John Singer Sargent (1856-1925), and James Abbott McNeill Whistler (1834-1903).

Art history textbooks are also the source of the evidence used in this study. This was drawn from all available books, published in English since 1960, that include illustrated surveys of American art of the late nineteenth century. A total of 37 such books were found. ${ }^{5}$ The data set for this study was created by listing every reproduction of every painting shown in these books by the six artists in the sample.

\section{$\underline{\text { Rankings of Painters and Paintings }}$}

The two most basic tabulations of the data can be presented immediately. Table 1 presents the ranking of painters by total illustrations. Not surprisingly, Homer and Eakins stand at the top of the ranking, nearly tied for first place, with an average of more than three illustrations per book. Whistler ranks third, and the remaining three artists are separated by relatively small margins.

Table 2 presents the ranking of individual paintings by total illustrations. Probably the most striking feature of the table is the dominant position of one painting. Eakins' The Gross Clinic appears in more than $70 \%$ of the books surveyed, while no other single painting is reproduced in even $30 \%$ of the books.

Several puzzles appear when Tables 1 and 2 are compared. One is that Sargent's portrait of Edward Boit's four daughters stands second in Table 2, ahead of any painting by Homer, even though Table 1 shows that Homer received in total more than three times as many illustrations as Sargent. Interestingly, Sargent places two paintings among the 11 in Table 2, as many as Homer and Whistler, both of whom stand far above him in Table 1. And another puzzle is that although 
Homer leads Table 1 in total illustrations, with an average of more than three illustrations per book, no individual painting by him appears in even a quarter of the books surveyed.

The comparison of the tables raises a number of interesting questions. Among the great number of paintings by the six artists considered here, why does one emerge as so much more important than any other? Why did a relatively minor painter - Sargent- produce an individual painting that is reproduced more often than any work by several artists whose work overall is considerably more important? And why did Homer, one of the two most important painters considered, fail to produce a single painting that ranks among the very most important American works of the late nineteenth century?

Importance in Art

Answering these questions requires an understanding of the source of importance of artists and their individual works. This was emphatically defined by one of the artists considered in this study. In the aftermath of his libel suit against the critic John Ruskin, James Whistler published a pamphlet attacking the competence not only of Ruskin, but of art critics in general. Whistler argued that only practitioners of a profession were qualified to judge its products; in support of this position he drew parallels between art and several other disciplines, including mathematics and medicine. Whistler declared that art would not suffer from a complete elimination of critics, arguing that critics were in any case superfluous:

Shall the painter then - I foresee the question - decide upon painting? Shall he be the critic and sole authority? Aggressive as is this supposition, I fear that, in the length of time, his assertion alone has established what even the gentlemen of the quill accept as the canons of art, and recognize as the masterpieces of work. ${ }^{6}$

As a young man, Whistler had arrived in Paris in 1855, where he not only made copies from the 
work of old masters at the Louvre, but experienced firsthand the impact on young artists of Courbet's challenge to the Academic establishment. ${ }^{7}$ In 1863, Whistler was delighted at the public debate occasioned by The White Girl, his entry in the Salon des Refusés, no doubt realizing that conservative critics' attacks on his work might gain him the kind of notoriety that would help to put him in a position to influence young artists, just as he had earlier been influenced by the rebel Courbet. ${ }^{8}$ When he wrote in the late 1870 s about the role of criticism, therefore, Whistler understood not only from academic study but from the experience of his own career that in the long run influence on other artists was the only real source of importance in art. Thus "in the length of time" artists themselves defined the canon of art by revealing in their work which painters, and paintings, had affected their practice.

As Whistler recognized, important painters are innovators, who change the work of their successors. Important individual paintings are those that embody important innovations. These formulations have clear implications for the puzzles raised above. Specifically, the puzzles must be resolved by considering not only why some artists' contributions were greater than others, but also why there were differences among artists in the extent to which their contributions were announced in individual paintings. Why did some artists introduce their innovations suddenly, and others gradually?

\section{$\underline{\text { A Typology of Artistic Innovators }}$}

Explaining how these differences in the timing of artists' contributions arise involves the recognition that there have been two very different types of innovation in the history of modern art. What distinguishes them is not their importance, but rather their source and the method by which they are produced. 
Modern artists who have produced experimental innovations have been motivated by the goal of presenting visual perceptions. Their objectives are imprecise, so they proceed toward them tentatively and incrementally, by a process of trial and error. Experimental artists typically change their paintings as they work, and consequently rarely make detailed preparatory sketches or plans in advance. The imprecision of their goals means that they often have trouble deciding when a painting is finished. Experimental painters build their skills gradually over their careers, learning and advancing incrementally toward their goals. Experimental innovations appear gradually over extended periods; they are rarely declared in any single work, but appear piecemeal in a large body of work.

In contrast, modern artists who have produced conceptual innovations have been motivated by a desire to communicate ideas or emotions. Their goals for a particular work can be stated precisely in advance, either as an intended outcome or a specific procedure for the work's production. They often make detailed sketches or plans for their paintings. Conceptual innovations appear suddenly, with the expression of a new idea, and they are often embodied in individual breakthrough works.

The life cycles of experimental and conceptual innovators tend to be very different. The long periods often required for the achievement of experimental innovations mean that they frequently occur late in an artist's career, but conceptual innovations, which are made quickly, can occur at any age. Major conceptual innovations are in fact most often made by young artists, who are not yet committed to existing conventions and methods, and can better perceive more radical deviations from them.

$\underline{\text { Painters and Methods }}$ 
Thomas Eakins was a conceptual artist. He was as methodical in preparing for his career as he would later be in preparing to make individual paintings. As a young man he spent four years studying at the Ecole des Beaux-Arts in Paris, working principally under the supervision of the prominent academic painter Jean-Léon Gérôme. Since Eakins knew he wanted to be a figure painter he had earlier studied anatomy in Philadelphia, not only taking lecture courses for artists, but actually enrolling at Jefferson Medical College to take courses intended for surgeons, in which the students observed clinics and performed dissections. ${ }^{9}$

Throughout his career, Eakins planned his paintings meticulously. He regularly made a variety of preparatory works, including drawings of individual figures, compositional sketches, and perspective studies. While early in his career he made most of these preparatory works in pencil, and later he usually instead substituted oil, in either case he often began the final work by transferring the image from the preparatory work to the canvas through the use of a grid. ${ }^{10}$ Kathleen Foster's study of Eakins' procedures repeatedly underlines the conceptual nature of his approach to art:

The construction of a perspective drawing is a conceptual, not a visual undertaking, as the typical emptiness of Eakins' drawings makes clear...

The master of perspective is an artist with a strong preliminary visualization of his or her subject, and a patient, even enthusiastic affection for planning...

Eakins' pictures were occasionally based on actual boat builders' plans. The use of such borrowed plans, or his own measured drawings, reminds us again that very little- perhaps nothing - in these drawings is done from observation; the space and the most important objects are entirely generated by the geometry of linear perspective and a set of measurements...

Perhaps the most remarkable thing about the relation between his finished paintings and the body of preparatory work that came before is the tight correlation between Eakins' first oil 
sketch of a given subject and the effect of his final canvas. ${ }^{11}$

The Gross Clinic was specifically intended to be a masterpiece. Well before its completion, Eakins wrote to a friend that "it is very far better than anything I have ever done." 12 Eakins made the painting for the Centennial Exhibition held in Philadelphia in 1876, and he appears to have devoted most of the preceding year to planning and executing it, much as young artists in nineteenth-century Paris would devote great time and effort to making individual major paintings aimed at attracting attention and establishing their reputations at the Salon. ${ }^{13}$

Eakins' careful preparations for The Gross Clinic are reflected not only in its technical complexity - perspective, lighting, and composition - but also in the layers of meaning embodied in his choice of subject. Elizabeth Johns has detailed how in this imposing work, more than 50 square feet in size, Eakins represented the high quality of American medicine, the excellence and egalitarian nature of the country's medical instruction, and the role of his home city in advancing science. ${ }^{14}$ For a painter who wished to use scientific knowledge and methods wherever possible to strengthen his art, it is not surprising that Eakins wanted to make this early masterpiece a tribute to science. A friend reported that Eakins wished to make the painting "the finest thing he could possibly do for so great an event," and a historian describes the work as "a summary of all that Eakins stood for at the time that he executed the painting." 15

Although The Gross Clinic was rejected by the selection committee for the Centennial Exhibition, perhaps because of the graphic nature of its portrayal of an operation, it has become increasingly celebrated since Eakins' death, and Table 2 reflects an often-expressed opinion that considers it "the greatest painting in American art." ${ }^{16}$ In fact, Table 2 provides a firmer basis for this opinion than has previously been available. The Gross Clinic appears in $70 \%$ of the texts 
surveyed for this study, a figure greater than any single painting made by any later American painter. Thus comparable studies found that Grant Wood's American Gothic, the most illustrated painting by an artist born during 1860-1900, appeared in $48 \%$ of the texts surveyed, that Willem de Kooning's Woman I, the most illustrated painting by an artist born during 1900-40, appeared in $36 \%$ of the respective texts, and that Chuck Close's Self-Portrait, the most illustrated painting by an artist born during 1940-60, appeared in $18 \%$ of the respective texts. ${ }^{17}$ Systematic surveys of the work of art historians therefore reveal that The Gross Clinic is generally considered more necessary to narratives of its period than any other painting in the history of modern American art.

Eakins made other important works later in his career, including The Swimming Hole that appears in Table 2, but the lack of appreciation for the Gross Clinic may have discouraged him from attempting other paintings that involved a comparable effort. Executed when Eakins was just 31, it remains his most ambitious, and best known, work.

Eakins was a prototypical conceptual artist: as Katherine Foster aptly observed, "His most creative moments were in his head; he did not 'explore' or 'discover' his subject as he worked."18 In discussing Eakins' The Pair-Oared Shell, Foster noted that a scholar was able to determine the exact time of day from the painting's shadow patterns, then drew a comparison:

Monet was painting the Seine, maybe at the same moment in the summer of 1872, with a similar modern ideology... His technique differed dramatically, of course, in its denial of the conceptual, drawn component of picture-making in favor of a completely perceptual, painted event. ${ }^{19}$

As Foster suggested, Monet was as completely an experimental artist as Eakins was a conceptual one: the French artist was the boldest of the Impressionists in working to create an art that would 
be based on observation rather than calculation. As the critic Théodore Duret explained, the Impressionists achieved "novel and unexpected effects. Stubbornly working in the open in all sorts of weather, they were able to seize and record those fugitive impressions of nature which painters working in their studios missed altogether." ${ }^{20}$

Duret's language is echoed in a statement made by Winslow Homer in 1880:

I prefer every time a picture composed and painted outdoors. This making studies and then taking them home to use is only half right. You get composition, but you lose freshness; you miss the subtle and, to the artist, the finer characteristics of the scene itself. ${ }^{21}$

Like Monet, Homer was an experimental artist. When the novelist Henry James first saw Homer's work in 1875, he took pains to describe the artist's intent and practice:

He is a genuine painter; that is, to see, and to reproduce what he sees, is his only care; to think, to imagine, to select, to refine, to compose, to drop in any of the intellectual tricks with which other people sometimes try to eke out the dull pictorial vision - all this Mr. Homer triumphantly avoids. He not only has no imagination, but he contrives to elevate this rather blighting negative into a blooming and honorable positive. ${ }^{22}$

James was correct in his belief that Homer's goals were visual, and that he wished to avoid calculation in his art. That Homer was not as bold in this practice as the young Monet may have reflected the circumstances of his early career. Homer was largely self-taught. He began his career as an illustrator, as a consequence of his apprenticeship to a commercial lithographer, so careful drawing of a scene was always the basis for his early work. The evidence of the evolution of Homer's art over the course of his long working life suggests that his development was a gradual process of moving away from planned images toward a freer and more spontaneous method based on perception. The result of his artistic development for American 
painting is often compared to that of Walt Whitman in poetry, as for example the critic Henry McBride remarked in 1936 that "Winslow Homer was the first of our painters to speak authoritatively in the native accent." ${ }^{23}$

Homer's single most often reproduced painting, Snap the Whip, was done in 1872, relatively early in his career. It was based on preparatory drawings of a group of boys playing, as well as a small oil study. ${ }^{24}$ Yet the final version of the painting differed considerably from the studies, as Homer changed the positioning of the figures and added a dramatic mountainscape as background. This was a common pattern for much of his career, as he often used drawings and oil sketches as elements of his finished works, combining and rearranging them to produce new images. ${ }^{25}$ Over time, his tendency was toward less reliance on preparatory work. In the late 1870s, he changed his usual watercolor technique: increasingly, rather than placing gouache over a pencil or chalk drawing, be began to put watercolor directly onto the paper. ${ }^{26}$

A curator named John Beatty came to know Homer in the last decade of the artist's life. In conversation with Beatty, Homer indicated the visual goal of his art: "When I have selected the thing carefully, I paint it exactly as it appears ... I try to paint truthfully what I see, and make no calculations." Homer stressed that his art came from careful observation of nature: "You must wait, and wait patiently until the exceptional, the wonderful effect or aspect comes. Then, if you have sense enough to see it - well, that is all there is to that." This led him to a practice reminiscent of that of Monet, as at one point Homer wrote to Beatty that "I work hard every afternoon from 4:30 to 4:40, that being the limit of the light that I represent, the title of my picture being Early Evening." Noting the parallel to the practice of Monet, who famously set out to capture atmospheric effects at specific times of day in his series paintings of the 1890s, Beatty 
remarked that "I have never heard of him expressing any special interest in the impressionists, and think it probable that he arrived at this all by himself., ${ }^{27}$

It appears that Homer did develop his method by himself, as over time his practice became more and more experimental, based on increasingly careful observation of nature and changes of his work in progress aimed at achieving subtle visual effects. ${ }^{28}$ The experimental nature of his art can account for the fact that although the textbooks judge his overall contribution to have been the greatest of any American artist of his time, no one or two of his paintings emerge as landmark works, and no single painting by Homer appears in even a quarter of the books. Homer's rough and direct technique that was initially considered a defect, but that subsequently came to be understood as a novel way of creating uniquely American images, can be illustrated by scores of different works: no less than 69 different paintings by Homer appear in the 37 books examined here, more than half of them reproduced just once. Like the experimental Monet, but unlike the conceptual Eakins, Homer thus produced no single work that is considered essential to an exposition of his achievement.

John Singer Sargent's treatment in the texts contrasts sharply with that of Homer. Thus as noted above, although Sargent's work receives less than a third of the total illustrations given to Homer, a single painting by Sargent appears in more books than any single work by Homer. That painting, of the four daughters of a friend of Sargent's, is also reproduced more than any single painting by Whistler, Cassatt, or Ryder, all of whom rank above Sargent in Table 1; it accounts for more than a quarter of Sargent's total illustrations, and it and one other portrait, also listed in Table 2, account for nearly half of that total.

As this evidence would suggest, Sargent was a conceptual artist. Although his great 
success as a society portrait painter gave him much greater fame and wealth than Eakins or Homer during these artists' lifetimes, his reputation has declined considerably since his death. Sargent's procedures emphasized careful preparation. He made pencil sketches of his patrons in order to decide on the poses for his portraits, just as he made preparatory sketches for his outdoor subjects before executing them in his studio. ${ }^{29}$ His most ambitious project, a cycle of murals illustrating the history of religion that he was commissioned to paint for the Boston Public Library, was based on hundreds of preparatory drawings. ${ }^{30}$

Sargent worked actively until his death at 69, but his two most celebrated paintings, listed in Table 2, were both done while he was in his 20s. In 1893, when Sargent was 37, Henry James wrote a review of an exhibition of his paintings. James praised Sargent for his clarity of purpose and confident execution: "It is difficult to imagine a young painter less in the dark about his own ideal, more lucid and more responsible from the first about what he desires. In an altogether exceptional degree does he give us the sense that the intention and the art of carrying it out are for him one and the same thing." James noted, however, that Sargent's recent work did not demonstrate development: "As he saw and 'rendered' ten years ago, so he sees and renders today; and I may add that there is no present symptom of his passing into another manner." James was troubled by Sargent's precocity, for “it offers the slightly 'uncanny' spectacle of a talent which on the very threshold of its career has nothing more to learn;" James found himself "murmuring, 'Yes, but what is left?' and even wondering whether it be an advantage to an artist to obtain early in life such possession of his means that the struggle with them, discipline, tâtonnement, cease to exist for him. May not his breed an irresponsibility ... on the part of the youthful genius who has, as it were, all his fortune in his pocket?" James concluded the review by expressing his fear that 
Sargent might never achieve "the highest result," which "is achieved when to this element of quick perception a certain faculty of brooding reflection is added." ${ }^{31}$

James' review of Sargent is a penetrating analysis of the career of a conceptual artist. And in retrospect James' fears appear to have been warranted, as only six of the illustrations of Sargent's paintings, or just $15 \%$ of the total, are of works done after James' essay was written. Sargent's principal contribution to portraiture, which lay chiefly in his unusual compositions and the striking poses of his sitters, had been made earlier, in his work of the early 1880s.

Sargent and Whistler knew each other for many years, but were never friends; the flamboyant Whistler dismissed Sargent as dull, and only an average painter. ${ }^{32}$ Whistler may have been jealous, for unlike Sargent he was never able to become a popular portrait painter. One source of this failure was Whistler's inability to finish portraits in a timely fashion, which appears to have been a consequence of his experimental method. ${ }^{33}$ A recent biography describes the open-ended process by which Whistler worked, with the consequent uncertainty as to how and when a painting would be completed:

Once a painting was started, it could take him years to complete it to his own fastidious measure of satisfaction. His pattern of work commonly consisted of an initial burst, a period of change, quite often major, followed by a period of neglect, then a final flurry to completion. ${ }^{34}$

Whistler's goals in art were visual, and he pursued them directly, normally painting and etching without preliminary drawing, and revising as often as necessary. Thus his disciples Elizabeth and Joseph Pennell observed that:

In the Nocturnes the sky and water are rendered with sweeps of the brush of exactly the right tone. How many times he made and wiped out that sweeping tone is another matter. When it was right, 
there it stayed... [A]t times, as he admits himself, he completed a Nocturne in a day. In some he got his effect at once, in others it came only after endless failures. ${ }^{35}$

In defending his lack of concern with recognizable subject matter, Whistler declared that "Art should be independent ... and appeal to the artistic sense of eye or ear, without confounding this with emotions entirely foreign to it." ${ }^{36}$ It was in fact Whistler's willingness to sacrifice subject matter in using color to evoke atmosphere that led to Ruskin's charge that the Nocturne in Black and Gold - tied for third place in Table 2 - was "a pot of paint flung in the public's face." In the ensuing trial, Whistler testified that he had made the painting in two days. When the defendant's counsel asked incredulously if he really charged the sum of two hundred guineas for just two days' work, Whistler responded famously, "No, I ask it for the knowledge I have gained in the work of a lifetime." ${ }^{37}$ The answer is revealing: although Whistler was hardly a modest man - an admirer, the American artist William Merritt Chase, described Whistler's public persona as "the brilliant, flippant, vain, and careless idler" - he defended the value of his art not through reference to his genius as a painter, but instead to his accumulation of knowledge in the course of a career that he had begun more than 20 years earlier. ${ }^{38}$

In 1862 the poet Charles Baudelaire, who had become Paris' leading critic of advanced art, praised Whistler's early etchings of the Thames for capturing the life of the river: "wonderful tangles of rigging, yardarms and rope; farragos of fog, furnaces and corkscrews of smoke; the profound and intricate poetry of a vast capital." 39 Henry James, who also moonlighted as an art critic, never liked the work of the Impressionists, but he recognized that Whistler shared their visual goals. ${ }^{40}$ In 1878 James criticized Whistler's paintings as little more than pleasant decorations, lacking in individuality: "Mr. Whistler paints in a manner to make it difficult to 
attach a high value to individual pieces. His manner is very much like that of the French 'Impressionists'., ${ }^{41}$ Later the English painter and critic, Walter Sickert, pointed to the visual basis of Whistler's work by remarking that his pictures "never remind us of the studio; they fascinate us first because they tell us that he has looked long and earnestly at Nature, because they show us well what he has seen, and because he has learned to see well." 42 After Whistler's death, Sickert made a criticism of his work that had often been applied to the Impressionists: "None of Whistler's paintings were finished. They were left off - which is another thing sometimes by force of circumstances, sometimes because he could do no more to them." ${ }^{43}$ Mary Cassatt was also an experimental artist. In this she resembled her mentor Edgar Degas, who greatly influenced her art. Late in her life, she recalled that "The first sight of Degas' pictures was the turning point in my artistic life." ${ }^{44}$ Cassatt first came in contact with Degas and his Impressionist colleagues in the mid-1870s, and her artistic goals and methods were affected considerably. So for example in 1879 Degas reported that Cassatt was "at this moment engrossed in the study of the reflection and shadow of flesh or dresses," in keeping with the Impressionists' concern with capturing the effects of light. ${ }^{45}$ A recent study concluded that "Cassatt hardly ever made preparatory drawings for her paintings... Half-finished paintings by Cassatt suggest that she painted alla prima, applying colors directly to the prepared ground, over only the most cursory indications of contour." ${ }^{46}$ Like Degas, Cassatt often worked in pastel, which allowed more spontaneous execution than oil, and examination of her pastels shows that she often changed her images, shifting the position, size, and shape of figures, in the course of their execution. ${ }^{47}$

Albert Pinkham Ryder was an experimental artist in the extreme. In an interview 
published in 1906, he recalled the key moment in his early education as a painter, when he first recognized his visual goal of capturing nature on canvas:

The old scene presented itself one day before my eyes framed in an opening between two trees. It stood out like a painted canvas - the deep blue of a midday sky - a solitary tree, brilliant with the green of early summer, a foundation of brown earth and gnarled roots ... Three solid masses of form and color - sky, foliage, and earth - the whole bathed in an atmosphere of golden luminosity ... I squeezed out big chunks of pure moist color and taking my palette knife, I laid on blue, green, white and brown in great sweeping strokes. As I worked I saw that it was good and clean and strong. I saw nature springing into life upon my dead canvas... Exultantly I painted until the sun sank below the horizon, then I raced around the fields like a colt let loose, and literally bellowed for joy. ${ }^{48}$

Ryder believed that "inspiration only can give birth to a work of art," but as in this first epiphany the inspiration he sought was visual, involving form and color. ${ }^{49}$ Ryder did not date his paintings, and typically worked on them for years; although few of his paintings can be dated with any precision, the most careful attempt to make a chronological list of them concluded that "he would often take ten or fifteen years, or more, to refine, change, and perfect the work." 50 The poor condition of most of his paintings today is a consequence of this extended process, as the many coats of paint and varnish he applied to his paintings often caused cracking when the outer layers failed to adhere to underlying layers. ${ }^{51}$ A visitor to his studio observed that Ryder worked with abandon: "When his mood impelled he scraped, glazed, scumbled and made the wildest experiments, simply to produce a fine bit of tone or beautiful color." ${ }^{, 52}$ A project that made $\mathrm{x}$ rays of Ryder's paintings "found evidence of a remarkable depth of pigment and concluded that Ryder had executed his paintings slowly, almost by trial and error." ${ }^{\text {,53 }}$ The subjects of Ryder's paintings often evolved during this process. A fellow artist reported that "Ryder had a funny, 
tentative way of working, and a picture might start as a daylighted landscape and end as a night scene." 54

Ryder was an experimental seeker, who created a visionary art. Clement Greenberg observed that his greatest works achieved their effect through "a subtle, rhythmic weaving together of color and value tones." ${ }^{, 55}$ In view of the nature of Ryder's method and his achievement, it is not surprising that Jackson Pollock declared that "The only American master who interests me is Ryder." 56

The dating of Ryder's paintings is so uncertain that no precise statements can be made about the timing of his most important contributions. Their study of Ryder's career led William Innes Homer and Lloyd Goodrich to the conclusion that what set Ryder apart from his lesser contemporaries was "his ability to grow and develop," and they believed that his most important phase was the period of roughly ten years beginning in the mid-1880s, from the time the artist was in his late 30s. Five of his paintings are illustrated in the textbooks four or more times; according to the chronology constructed by Homer and Goodrich, all of these were executed during this period or later. ${ }^{57}$

\section{Quantitative Evidence}

The textbook illustrations can be used to examine systematically two implications of the analysis presented above of the differences between experimental and conceptual artists. The first of these involves the production of landmark works. The sudden nature of the introduction of conceptual innovations, and the conceptual artist's ability to prepare carefully for major individual statements, imply that the careers of conceptual artists should be dominated to a greater extent by a small number of works than would be the case for experimental artists. To 
consider this prediction for the artists studied here, Table 3 shows the percentage of each artist's total illustrations accounted for by the $10 \%$ of the artist's reproduced paintings that receive the most illustrations.

The evidence of Table 3 supports the prediction. The two conceptual artists in the sample, Sargent and Eakins, hold the top two positions in the table, as for both more than $40 \%$ of their total illustrations are due to just $10 \%$ of their illustrated paintings. The four experimental artists all have values below 40\%, and the entries for Homer and Ryder are below 30\%. The decisions of textbook authors thus indicate that the conceptual artists' careers were more heavily dominated by a small number of works than were those of the experimentalists.

The second implication of the analysis that can be examined with the textbook evidence concerns the timing of the artists' primary contributions. Conceptual innovations can be formulated and developed more rapidly than experimental ones, and consequently tend to occur earlier in artists' careers. Table 4 presents evidence that bears on this prediction: assigning each artist's illustrations to the specific years in which the works they represent were executed, the artist's median year is that which divides this distribution of illustrations chronologically into two groups of equal size. ${ }^{58}$

The evidence of Table 4 again supports the prediction. Half of Sargent's total illustrations represent work he did by the time he was 28, and for Eakins the corresponding age was 33. In contrast, the three experimental artists in the table were all older in the years represented by their median illustrations; Whistler was 37, and Homer and Cassatt were both above 40. Thus the textbooks indicate that the career patterns of the conceptual and experimental artists were systematically different, as the former arrived at their major achievements at younger 
ages than the latter.

\section{Eakins, Photography, and Color}

It has long been known that Thomas Eakins had a serious interest in photography - he owned a camera by 1881, he set up a darkroom in his house, and he sometimes used photographs in conjunction with other forms of preparatory works to help him capture elements of the subjects he portrayed in his paintings. ${ }^{59}$ Yet the specific role of photography in Eakins' art remained uncertain until recently, with the publication of new research in connection with a retrospective exhibition of Eakins' work. Two conservators at the Philadelphia Museum of Art presented evidence that Eakins had begun work on paintings by projecting photographic images onto his painting surfaces. They found that he had done this in two ways. In three paintings and a watercolor executed during 1881-82, infrared reflectography revealed that Eakins had traced photographic images projected onto the primed canvas or paper in order to make the underdrawings for the works. And in a number of other works, including paintings done as early as 1872 , examination of the painting surface with a microscope revealed that Eakins had used a stylus to mark key reference points on the outlines of specific figures from photographs that had been projected onto the work in progress. The marks, which Eakins used as guides in painting the relevant figures, were scratched into the paint at various stages during the production of the paintings. $^{60}$

The discovery that Eakins had used photographic projections in making his paintings came as a surprise to many historians because Eakins had never mentioned doing this, and his widow had declared that he disliked working from photographs in any way. Both the artist's reticence and his widow's denial appear understandable in view of the widespread attitude 
among art critics and historians, from Eakins' day to the present, that the use of photographic projections is evidence of an artist's lack of skill. ${ }^{61}$ But while art world prejudices can thus account for Eakins' concealment of his use of photographic projections, it should perhaps come as no real surprise that he used them. Eakins' overriding goal was to achieve realism in his paintings: as he told a friend, he wanted viewers of his works to be able to tell the time of day, the temperature, the season and "what kind of people are there and what they are doing and why they are doing it." ${ }^{\prime 2}$ He pursued this goal systematically, through careful planning of his works. ${ }^{63}$ Eakins' use of projected photographic images is consequently consistent with his approach to art throughout his life: his careful study of mechanical drawing and perspective in high school, and of anatomy as a young artist, signaled his desire to use all available scientific methods in pursuit of achieving accuracy3 in his images. As technological advances made photography less expensive and easier to use, it is not surprising that he would add it to the scientific tools he had invested in acquiring earlier.

In the course of examining Eakins' paintings, the conservators found one element for which his procedures contrasted sharply with the careful preconception of his compositions, as they observed that Eakins "often followed an indirect course of successive approximations toward a harmonious arrangement and ordering of color." Color frustrated Eakins. Early in his career he complained of his inability to use color without the need to "change \& bother, paint in \& out." Color presented problems that were extremely complicated: "there is the sun \& gay colors \& a hundred things you never see in a studio light \& ever so many botherations that no one out of the trade could ever guess at." ${ }^{\circ 4}$

Unable to plan the color of his works as precisely as he could their composition, Eakins 
developed a procedure that made his paintings "like multilayered workbooks in the study and control of color relationships and overall brightness." Lacking a reliable way of calculating color relationships in advance, Eakins followed a process in which he applied layers of paint, working incrementally from bright colors to darker ones in the course of executing a painting. Eakins clearly considered working by stages to be the lesser of two evils. Thus he was appalled by Delacroix's attempts "to seek the tones throughout his painting at the same time;" he found the results "abominable," and attributed this to the fact that Delacroix worked intuitively, and thus “didn't have any process" to find the proper color relationships. ${ }^{65}$

Eakins lacked the ability to plan the use of color fully in advance. Forced by this to abandon his preferred procedure of strict preconception of his images, Eakins recognized that he would have to make adjustments in color relationships in the process of executing his paintings. His solution was to circumscribe the scope of any single decision to the greatest extent possible, by following a systematic process that divided the determination of color relationships into a series of decisions. This process effectively allowed the cautious Eakins to reduce the damage from a mistake, for an error at any intermediate stage could be rectified later in the proceedings.

Eakins' response to the problem of color is intriguing and suggestive. Even extreme conceptual artists may be unable to plan their works completely in advance: constraints imposed by the limitations of their own knowledge or ability, or of prevailing technology, may make it impossible for them both to make all significant decisions in advance and to achieve results they judge to be acceptable. Eakins' procedure suggests that the solution least likely to compromise their goals in such a case may be to design a process that advances systematically, and breaks any decision that must be made in the course of execution into a series of smaller decisions. Such a 
solution may in effect diversify the risk associated with making decisions in the course of executing the work, by minimizing the damage done by any single mistake, and providing opportunities to correct it. The Philadelphia conservators note that they consider their research on Eakins incomplete, for examination of more his works may reveal more widespread use of traced underdrawings. ${ }^{66}$ Yet what they may not recognize is that their consideration of Eakins' approach to color appears to open up a wider research agenda, of examining how other conceptual artists have adapted to situations in which they were unable to produce their work through strict preconception.

\section{Conclusion}

American painters were not major contributors to the most advanced modern art of the late nineteenth century. Yet Americans did develop a range of approaches to producing their art that was as diverse as that of French artists of the time. The extreme conceptual approach of Thomas Eakins lay at one end of the spectrum. Eakins systematically incorporated scientific knowledge and methods into his work in pursuit of his goal of realism. No French painter of the era pursued his goals more methodically than Eakins, and perhaps only Seurat, who also believed in applying scientific knowledge to art, could compare to Eakins in the steadfastness with which he sought to eliminate chance and uncertainty from art. At the opposite extreme in method was the approach of Albert Ryder, who developed a visual art based on ceaseless experimentation. Ryder's constant revision of his works in progress, and persistent unwillingness to consider them finished, were as basic to his approach as they were to those of Cézanne or Degas.

Although less extreme in their approaches, the practices of the other artists considered here clearly identify the basis of their methods. Winslow Homer was an experimental artist, who 
appears to have moved gradually toward an art based increasingly on perception and spontaneity as he grew older. Mary Cassatt and James Whistler followed experimental approaches not unlike those of their Impressionist friends. And John Singer Sargent was a conceptual painter who produced final versions of his paintings after using sketches to fix the images in his mind.

As was the case for their French contemporaries, the life cycles of the American artists reflected their methods. The conceptual Eakins and Sargent matured early and made landmark works, whereas the experimentalists Cassatt, Homer, Ryder, and Whistler developed more slowly, and made their principal contributions in larger bodies of work.

That American artists were much less influential than their French counterparts in the late nineteenth century was in part a consequence of their failure to produce radical innovations in an era that increasingly demanded them, and in part a result of the general assumption of American cultural inferiority that reduced their ability to affect the development of younger artists. But this study has shown that American artists developed approaches to art no less considered, and no less subtle, than their French counterparts. While the expatriates did this through their association with leading French artists, those who remained in the United States independently created a variety of distinctive styles of art. 


\section{$\underline{\text { Footnotes }}$}

I thank Robert Jensen for discussions, Peter Northup for research assistance, and the National

Science Foundation for financial support.

1. For discussion see David W. Galenson, Painting outside the Lines: Patterns of Creativity in Modern Art (Cambridge: Harvard University Press, 2001), Chaps. 5-6.

2. Lloyd Goodrich, Winslow Homer (New York: Macmillan, 1944), p. 221; Kathleen A. Foster, Thomas Eakins Rediscovered (Philadelphia: Pennsylvania Academy of the Fine Arts, 1997), p. 60.

3. Galenson, "Quantifying Artistic Success: Ranking French Painters - and Paintings - from Impressionism to Cubism," Historical Methods, Vol. 35, No. 1 (Winter 2002), pp. 5-20; Galenson, "Measuring Masters and Masterpieces: French Rankings of French Painters and Paintings from Realism to Surrealism," Histoire et Mesure, Vol. 17, No. 1-2 (2002), pp. 47-85.

4. See the appendix for a listing of these texts.

5. These books are listed in the appendix.

6. Whistler, The Gentle Art of Making Enemies (New York: Dover Publications, 1967), pp. $26,30,33$.

7. E.g. see E. R. and J. Pennell, The Life of James McNeill Whistler, sixth ed. (Philadelphia: J. B. Lippincott, 1919), pp. 46-47.

8. John Rewald, The History of Impressionism, Revised ed. (New York: Museum of Modern Art, 1961), pp. 81, 86; Ronald Anderson and Anne Koval, James McNeill Whistler (New York: Carroll and Graf, 1995), pp. 133-34.

9. Lloyd Goodrich, Thomas Eakins (Cambridge: Harvard University Press, 1982), Vol. 1, Chaps. 1-2.

10. Foster, Thomas Eakins Rediscovered, Chaps. 7-8.

11. Ibid., pp. 59, 60, 68, 74 .

12. Goodrich, Thomas Eakins, Vol. 1, p. 123. 
13. Ibid., Vol. 1, pp. 123-28; Galenson, "Masterpieces and Markets: Why the Most Famous Modern Paintings Are Not by American Artists," Historical Methods, Vol. 35, No. 2 (Spring 2002), pp. 68-70.

14. Elizabeth Johns, Thomas Eakins (Princeton: Princeton University Press, 1983), Chap. 3.

15. John Wilmerding, editor, Thomas Eakins (1844-1916) and the Heart of American Life (London: National Portrait Gallery, 1993), p. 80.

16. E. g. Henry McBride, The Flow of Art (New Haven: Yale University Press, 1997), p. 130; Michael Fried, Realism, Writing, Disfiguration (Chicago: University of Chicago Press, 1987), p. 6.

17. Galenson, "Before Abstract Expressionism: Ranking American Painters and Paintings of the Early Twentieth Century," (unpublished paper, University of Chicago, 2005), Table 3; Galenson, "Was Jackson Pollock the Greatest Modern American Painter? A Quantitative Investigation," Historical Methods, Vol. 35, No. 3 (Summer 2002), p. 119; Galenson, "The Reappearing Masterpiece: Ranking American Artists and Art Works of the Late Twentieth Century," NBER Working Paper 9935 (August 2003), Table 3.

18. Foster, Thomas Eakins Rediscovered, p. 74.

19. Ibid., p. 69.

20. Théodore Duret, Manet and the French Impressionists (Philadelphia: J. B. Lippincott, 1910), p. 71.

21. Helen A. Cooper, Winslow Homer Watercolors (Washington: National Gallery of Art, 1986), p. 55.

22. Henry James, The Painter's Eye (Madison: University of Wisconsin Press, 1989), p. 96.

23. McBride, The Flow of Art, p. 331.

24. John Wilmerding, Winslow Homer (New York: Praeger, 1972), p. 87.

25. Goodrich, Winslow Homer, p. 33.

26. Cooper, Winslow Homer Watercolors, pp. 55-57.

27. Goodrich, Winslow Homer, pp. 221-24.

28. Ibid., p. 222.

29. Patricia Hills, John Singer Sargent (New York: Whitney Museum, 1986), pp. 256-59. 
30. Trevor Fairbrother, John Singer Sargent (New York: Harry N. Abrams, 1994), p. 87.

31. James, Painter's Eye, pp. 216-18, 223, 227-28.

32. Stanley Olson, John Singer Sargent (New York: St. Martin’s Press, 1986), p. 96.

33. Denys Sutton, James McNeill Whistler (London: Phaidon Press, 1966), p. 38.

34. Ronald Anderson and Anne Koval, James McNeill Whistler (New York: Carroll and Graf Publishers, 1995), p. 97.

35. E. R. and J. Pennell, The Life of James McNeill Whistler, pp. 50, 116.

36. Whistler, The Gentle Art of Making Enemies, p. 127.

37. Linda Merrill, A Pot of Paint (Washington: Smithsonian Institution Press, 1992), p. 148.

38. Anderson and Koval, James McNeill Whistler, p. 275. Perhaps blinded by Whistler's public pose, scholars often appear to have ignored what the artist actually said at his trial. So for example Richard Dorment quotes Whistler's famous words, then remarks: "With these words Whistler was introducing the novel idea that the work of art did not depend on the amount of time it took to paint it but on the far more intangible concept of the artist's genius;" Richard Dorment and Margaret F. MacDonald, James McNeill Whistler (New York: Harry N. Abrams, 1995), p. 138. Dorment appears twice mistaken. First the idea that the value of a work of art could depend on the artist's genius would hardly have been a novel one in Whistler's time. A sixteenth-century author attributed to Michelangelo the statement that "I value highly the work done by a great master even though he may have spent little time over it. Works are not to be judged by the amount of useless labor spent on them but by the worth of the skill and mastery of their author;" Rudolf and Margot Wittkower, Born Under Saturn (New York: Random House, 1963), p. 61. And second, the argument Dorment attributes to Whistler is not the one Whistler actually made: whereas "genius" is normally used to refer to natural ability, Whistler specifically invoked knowledge acquired through experience as the justification for the price of his painting.

39. Charles Baudelaire, Art in Paris 1845- 1862 (Oxford: Phaidon, 1981).

40. E. g. see James, The Painter's Eye, pp. 114-15.

41. James, The Painter's Eye, p. 165.

42. Walter Sickert, The Complete Writings on Art (Oxford: Oxford University Press, 2000), p. 5 .

43. Ibid., p. 193. 
44. Nancy Mowll Mathews, Cassatt and Her Circle (New York: Abbeville Press, 1984), p. 321.

45. Ibid., p. 148.

46. Judith A. Barter, Mary Cassatt (New York: Harry N. Abrams, 1998), p. 118.

47. Ibid., p. 217.

48. William Innes Homer and Lloyd Goodrich, Albert Pinkham Ryder (New York: Harry N. Abrams, 1989), p. 20.

49. Ibid., p. 53.

50. Ibid., p. 54.

51. Ibid., pp. 175-84.

52. Ibid., p. 226.

53. Ibid., p. 122.

54. Ibid., p. 180.

55. Clement Greenberg, The Collected Essays and Criticism, Vol. 2 (Chicago: University of Chicago Press, 1986), p. 180.

56. Pepe Karmel, ed., Jackson Pollock: Interviews, Articles, and Reviews (New York: Museum of Modern Art, 1999), p. 16.

57. The chronology is given in ibid., pp. 234-38. The problem of dating Ryder's work is illustrated by The Race Track, which is illustrated in five textbooks. The entry for the painting in the chronology in ibid., p. 238, dates the painting as "late 1880s to early 1890s." Yet in a separate discussion of the painting, Homer and Goodrich note that "in 1910 Ryder had agreed to sell the picture, but refused to let the buyer take it because it was not finished;" ibid., p. 164. The poet Paul Valéry observed of Degas that "I am convinced that he felt a work could never be called finished, and that he could not conceive how an artist could look at one of his pictures after a time and not feel the need to retouch it;" Degas, Manet, Morisot (Princeton: Princeton University Press, 1960), p. 50. The statement seems equally applicable to Ryder.

58. Ryder is omitted because of the extreme imprecision in the dating of his paintings.

59. E.g. see Foster, Thomas Eakins Rediscovered, Chap. 11. 
60. Darrel Sewell, Thomas Eakins (Philadelphia: Philadelphia Museum of Art, 2001), pp. 225-38.

61. Ibid., p. 226.

62. Goodrich, Thomas Eakins, Vol. 1, p. 31.

63. The conservators observe that Eakins" "general inclination" was "to isolate problems at the outset and address each by the appropriate means;" Sewell, Thomas Eakins, p. 237.

64. Ibid., p. 353.

65. Ibid., pp. 353-57.

66. Ibid., p. 234. 
Appendix. The 37 books surveyed for this study are listed here, ordered by date of publication. The 6 books used to select the artists included in the sample are indicated by asterisks.

1. David M. Robb and J. J. Garrison, Art in the Western World, Fourth edition (New York: Harper and Row, 1963).

2. Samuel M. Green, American Art (New York: Ronald Press, 1966).

3. Barbara Novak, American Painting of the Nineteenth Century (New York: Praeger, 1969).

4. James Thomas Flexner, Nineteenth Century American Painting (New York: G. P. Putnam's Sons, 1970).

5. George Heard Hamilton, 19th and 20th Century Art (New York: Harry N. Abrams, 1970).

6. Daniel M. Mendelowitz, A History of American Art, Second edition (New York: Holt, Rinehart and Winston, 1970).

7. Dale G. Cleaver, Art, Second edition (New York: Harcourt Brace Jovanovich, 1972).

8. Abraham A. Davidson, The Story of American Painting (New York: Galahad Books, 1974).

9. Harold Spencer, The Image Maker (New York: Charles Scribner's Sons, 1975).

10. John Canaday, Mainstreams of Modern Art, Second edition (Fort Worth: Harcourt Brace Jovanovich, 1981).

11. *Sara Cornell, Art (Englewood Cliffs: Prentice-Hall, 1983).

12. Ralph A. Britsh and Todd A. Britsch, The Arts in Western Culture (Englewood Cliffs: Prentice-Hall, 1984).

13. Robert Rosenblum and H. W. Janson, 19th -Century Art (New York: Harry N. Abrams, 1984).

14. Edmund Burke Feldman, Thinking About Art (Englewood Cliffs: Prentice-Hall, 1985).

15. H. H. Arnason, History of Modern Art, Third edition (New York: Harry N. Abrams, 1984).

16. Hugh Honour and John Fleming, The Visual Arts: A History, Second edition (Englewood Cliffs: Prentice-Hall, 1986). 
17. Gerald Needham, 19th-Century Realist Art (New York: Harper and Row, 1988).

18. Frederick Hartt, Art, Third edition (Englewood Cliffs: Prentice-Hall, 1989).

19. Michael Wood, Bruce Cole, and Adelheid Gealt, Art of the Western World (New York: Simon and Schuster, 1989).

20. Terence Greider, Artist and Audience (Fort Worth: Holt, Rinehart and Winston, 1990).

21. Horst de la Croix, Richard G. Tansey, and Diane Kirkpatrick, Gardner's Art Through the Ages, Ninth edition (San Diego: Harcourt Brace Jovanovich, 1991).

22. Sam Hunter and John Jacobus, Modern Art, Third edition (Englewood Cliffs: PrenticeHall, 1992).

23. Stella Pandell Russell, Art in the World, Fourth edition (Fort Worth: Harcourt Brace Jovanovich, 1993).

24. *Laurie Schneider Adams, A History of Western Art (New York: Harry N. Abrams, 1994).

25. Edward Lucie-Smith, American Realism (New York: Harry N. Abrams, 1994).

26. William Fleming, Arts and Ideas, Ninth edition (Fort Worth: Harcourt Brace, 1995).

27. *Marilyn Stokstad, Art History (New York: Harry N. Abrams, 1995).

28. *Matthew Baigell, A Concise History of American Painting and Sculpture, Revised edition (New York: Harper and Row, 1996).

29. *Robert Hughes, American Visions (New York: Alfred A. Knopf, 1997).

30. David G. Wilkins, Bernard Schultz, and Katheryn M. Linduff, Art Past, Art Present, Third edition (New York: Harry N. Abrams, 1997).

31. Rita Gilbert, Living with Art, Fifth edition (Boston: McGraw Hill, 1998).

32. Richard R. Brettell, Modern Art, 1851-1929 (Oxford: Oxford University Press, 1999).

33. John McCoubrey, American Tradition in Painting, New edition (Philadelphia: University of Pennsylvania Press, 1999).

34. Jay Tobler, editor, The American Art Book (London: Phaidon, 1999). 
35. Barbara Groseclose, Nineteenth-Century American Art (Oxford: Oxford University Press, 2000)

36. Martin Kemp, editor, The Oxford History of Western Art (Oxford: Oxford University Press, 2000).

37. *David Bjelajac, American Art (New York: Harry N. Abrams, 2001). 
Table 1: Ranking of Painters by Total Illustrations

\begin{tabular}{|l|c|}
\hline Artist & Total Illustrations \\
\hline \hline 1. Homer & 123 \\
\hline 2. Eakins & 121 \\
\hline 3. Whistler & 64 \\
\hline 4. Cassatt & 45 \\
\hline 5. Ryder & 40 \\
\hline 6. Sargent & 39 \\
\hline
\end{tabular}

Source: $\quad$ This and subsequent tables are based on the data set constructed for this study. See text and appendix for description. 
Table 2: Ranking of Paintings by Total Illustrations

\begin{tabular}{|c|c|c|c|c|}
\hline Ranking & Illustrations & Artist, Title & Date & Location \\
\hline 1 & 26 & Eakins, The Gross Clinic & 1875 & Philadelphia \\
\hline 2 & 11 & $\begin{array}{l}\text { Sargent, The Daughters of Edward Darley } \\
\text { Boit }\end{array}$ & 1882 & Boston \\
\hline $3 t$ & 10 & $\begin{array}{l}\text { Eakins, Champion Single Sculls } \\
\text { (Max Schmitt in a Single Skull) }\end{array}$ & 1871 & New York \\
\hline $3 t$ & 10 & $\begin{array}{l}\text { Whistler, Nocturne in Black and Gold: The } \\
\text { Falling Rocket }\end{array}$ & 1875 & Detroit \\
\hline 5 & 9 & Homer, Snap the Whip & 1872 & $\begin{array}{l}\text { Youngstown, } \\
\text { Ohio }\end{array}$ \\
\hline 6 & 8 & $\begin{array}{l}\text { Whistler, Arrangement in Grey and Black: } \\
\text { Portrait of the Painter's Mother }\end{array}$ & 1871 & Paris \\
\hline $7 \mathrm{t}$ & 7 & Cassatt, The Boating Party & 1894 & $\begin{array}{l}\text { Washington, } \\
\text { D.C. }\end{array}$ \\
\hline $7 \mathrm{t}$ & 7 & Cassatt, The Child's Bath & 1893 & Chicago \\
\hline $7 \mathrm{t}$ & 7 & Eakins, The Swimming Hole & 1885 & Forth Worth \\
\hline $7 \mathrm{t}$ & 7 & Homer, Prisoners from the Front & 1866 & New York \\
\hline $7 \mathrm{t}$ & 7 & $\begin{array}{l}\text { Sargent, Madame X (Madame Pierre } \\
\text { Gautreau) }\end{array}$ & 1884 & New York \\
\hline
\end{tabular}


Table 3: Percentage of Each Artist's Total Illustrations Accounted for by the Artist's Most-Illustrated Paintings

\begin{tabular}{|l|c|}
\hline Artist & $\begin{array}{c}\% \text { of total illustrations from } \\
\text { most-illustrated 10\% of } \\
\text { paintings }\end{array}$ \\
\hline \hline Sargent & 46.2 \\
\hline Eakins & 43.0 \\
\hline Whistler & 37.5 \\
\hline Cassatt & 31.1 \\
\hline Homer & 28.5 \\
\hline Ryder & 25.0 \\
\hline
\end{tabular}


Table 4: Artists' Ages in Years of Median Illustrations

\begin{tabular}{|l|c|c|}
\hline Artist & Year & Age \\
\hline \hline Cassatt & 1891 & 46 \\
\hline Homer & 1877 & 41 \\
\hline Whistler & 1871 & 37 \\
\hline Eakins & 1877 & 33 \\
\hline Sargent & 1884 & 28 \\
\hline
\end{tabular}

